\title{
European Union Enlargement and the new Peripheral Regions: Political, Economic and Social, and Related Issues - A Case of Warmia and Mazury Region ${ }^{1}$
}

\author{
ARKADIUS ŻUKOWSKI \&MARCIN CHEŁMINIAK
}

\begin{abstract}
This paper analyses the problems of the new peripheral regions after the European Union enlargement. The last EU enlargements in 2004 and 2007 were the logical consequences of political, social and economic changes associated with the break-up of the Soviet Union and the disintegration of the Communist Bloc. These two enlargements led to substantial geopolitical consequences. The European Union's demographic and territorial potential increased by around one-third. At the same time, the European Union structures moved east and southwards. In 2004, one of the Polish regions, the Warmia and Mazury region, faced some new challenges associated with the Polish accession to the EU. The years of Poland's membership in the European Union have been a period of gaining experience in submitting EU projects for the region, and in allocating financial resources properly. The total effect of this period is rather positive. However, we must not forget that many negative economic and social phenomena still occur (e.g., a high unemployment rate, emigration of young educated people, etc.). Politically, a new challenge for the Warmia and Mazury region is going to be a continuation and development of the cross-border cooperation with the Kaliningrad region. Poland's accession to the EU has had no positive impact on improving the Polish-Russian relations at the central decision-making level.
\end{abstract}

KEYWORDS: • European Union • regional development • new peripheral regions $\bullet$ Warmia and Mazury region

CORRESPONDENCE AdDRESS: Professor Arkadiuz Żukowski, Ph. D., Institute of Political Sciences, University of Warmia and Mazury, Szrajbera Str. 11, 10-007 Olsztyn, Poland, email: arkadiusz.zukowski@uwm.edu.pl. Marcin Chełminiak, Ph. D., Institute of Political Sciences, University of Warmia and Mazury, Szrajbera Str. 11, 10-007 Olsztyn, Poland, e-mail: elbing@wp.pl. 

Regions: Political, Economic and Social Aspects, and Related Issues - A Case of Warmia and Mazury Region

The European Union (EU) has attempted to formulate the objectives of its policy towards the Central and Eastern European countries since the first half of the 1990s. At that time, the situation there was unstable. In this case, one of the first EU initiatives was the Stability and Growth Pact proposed by French Prime Minister Balladur in 1993. The Pact was the first component of the Common Foreign and Security Policy (CFSP) proclaimed in the Maastricht Treaty. First of all, the CFSP was supposed to strengthen stability in the whole of Europe by encouraging post-communist countries to conclude bilateral treaties concerning recognition of mutual frontiers, establishing friendly and good neighbour relations, and respecting the rights of national and ethnic minorities (Zięba 2000: 10). From an EU perspective, the primary purpose was to reduce social and economic imparities between the 'old' Member States and the new Member States from Central and Eastern Europe.

The last EU enlargements in 2004 and 2007 were the logical consequences of political, social and economic changes associated with the break-up of the Soviet Union and the disintegration of the Communist Bloc. These two enlargements led to substantial geopolitical consequences. The European Union's demographic and territorial potential increased by around one-third. At the same time, the European Union structures moved east and southwards.

The admission of the ten new Member States into the European Union in 2004, and another two new Member States in 2007, was an exceptional undertaking for some reasons:

- for the first time in EU history, so many countries were simultaneously admitted into the European Union;

- the majority of the new Member States were post-communist countries;

- $\quad$ peripheral regions are in most new Member States.

EU peripheral regions are understood as regions of the external EU border, and also as regions that (according to social and economic indicators) stand out from the average EU standards.

The peripheral regions are mainly characterised by the following economic indexes:

- $\quad$ the size of Gross Domestic Product (GDP)

- GDP per capita and per worker 
The other indexes considering economic and social issues are:

- investment in $\mathrm{R} \& \mathrm{D}$,

- unemployment rate,

- level of education.

Old dirty industries have frequently dominated the peripheral regions. Such regions are not economically competitive. Another perspective is measuring accessibility to these regions that are isolated due to lack of proper transport infrastructure.

The term "peripheral regions" should not be mistaken for the term "outermost regions"

After the European Union's biggest enlargement, the new European peripheral regions face not only economic, but also essential political and social challenges.

\section{The Polish Peripheral Regions and EU Enlargement}

The integration of Poland with EU structures constituted one of the most important objectives of the Polish foreign policy after 1989. The most powerful political parties supported this direction of Polish diplomacy by reaching a special consensus. Part of the Polish political and scientific elite considers Poland's integration with the EU premature ${ }^{3}$ and thereby comparing it to some great events from the Polish history such as adoption of Christianity in 996, or establishing the Polish-Lithuanian Union in 1596 (Kukliński, 1999: 11). Poland undoubtedly treats the EU membership as a chance for its permanent presence in the Western political and economic structures, as well as a chance for providing the progress of civilization in its eastern regions that could be defined as peripheral regions (according to the European economic and social standards).

One of the most important spheres of EU activity is EU regional policy. There are three areas of support in the framework of EU regional policy:

1. Development promotion and adoption of structural changes in lessdeveloped regions (with a GDP per capita of less than 75 percent of the EU average).

2. Support for the regions with structural problems caused by the domination of inefficient branches of economy that are not included in the number one support scheme.

3. Support for restructuring the labour market by increasing employment possibilities and raising qualifications (Kruszewska-Gagoś, 2006: 34).

Poland's integration with the EU aimed, among other things, to stop the process of widening the gap between regions. Two divisions mostly determine the process: 
1. Traditional division of the country: city - village. Nowadays non agricultural sectors of economy determine abilities for development. Only great cities (e.g. Warsaw, Poznan, Krakow and Wroclaw) with diversificated branches of economy, connected with Europe by relatively good transport and telecommunication infrastructure, rich in different institutions, including research and development institutions, inhabited by well educated population are able to be competitive in global economy. Socio-economic changes in Poland were most dynamic in the cities, especially large cities, and much slower in the rural areas. The changes were characterized by a high level of spatial differentiation. It is referred not only to the rate of transformation, but also to its quality and directions, as well as the benefits and losses they bring about. We can see also that the demographic and economic disproportion between suburban and peripheral areas is becoming greater too. One of the most important phenomena differentiating the socioeconomic situation of analyzed regions is, on the one hand, the influx of urban population (usually well educated and affluent) to suburban area, and on the other hand, the outflow or stagnation of population in the peripheries (village areas), which makes the age and sex structure, already out of balance or even worse. ${ }^{4}$

2. Eastern and Western parts of the country: this division is historically conditioned. Since the Middle Ages, the western part of the present Polish territory has been better developed than the eastern one. The three partitions of Poland (carried out by Russia, Prussia and Austria in 1772, 1793, and 1795) widened the gap between regions. Even today, the former borders from the partition period are still visible in the socio-economic sphere. After the transition of the political system to parliamentary democracy in Poland in 1989, the Polish eastern territories showed significantly less ability to meet the requirements of an open and competitive economy based on knowledge. The present Polish eastern regions are lagging behind due to the above-mentioned structural retardation (Gorzelak, 2002: 62).

Polish experts correctly pointed out that after the 2004 EU enlargement there would be "(...) peripherisation of peripheries in mutual European space. (...) The Polish eastern regions will become eastern peripheries of the EU (like eastern regions of Slovakia, Hungary, and the Baltic countries) where GDP per capita is $1 / 4$ or $1 / 3$ of the EU average; those regions will border on non-EU regions where GDP per capita is less than 1/7 or even 1/10 of the EU average. Moreover, when visas are required and restrictions are put on cross-border traffic, they are going to significantly limit the cross-border cooperation between the new EU peripheries and their direct neighbours" (Gorzelak, 2002: 62-63).

Following the 2004 EU enlargement, as many as five Polish voivodships (Warmia and Mazury, Lubelskie, Podlasie, Subcarpathia, and Swietokrzyskie) are among the peripheral regions of the European Union with the lowest GDP per capita. The new EU external border with the three Eastern European countries (Russia, 
Belarus, and Ukraine) is around $3000 \mathrm{~km}$ long (without taking into account the Finnish-Russian border that is $1313 \mathrm{~km}$ long). Among the countries that joined the European Union in May 2004 there is only Poland that has the longest border with the non-EU countries. The border is almost $1200 \mathrm{~km}$ long (more than $200 \mathrm{~km}$ with the Kaliningrad region of the Russian Federation, $418 \mathrm{~km}$ with Belarus, and $535 \mathrm{~km}$ with Ukraine).

The basic elements of the profile and mutual features of the Polish peripheral regions (that are also border regions) are the following:

- The regions are in the shadow of the border areas, and they have features characteristic of the vicious circle syndrome that blocks their further development.

- All the regions hold the record of a negative migration balance and a high rate of foreign migration.

- Demographic losses caused by a significant outflow of highly educated young people from businesses (Kawałko, 2006: 5).

We should also add that the regions have a high unemployment rate and poorly educated people.

\section{Warmia and Mazury Region after the EU Enlargement}

One of the new EU peripheral regions that perfectly show the problems is the Warmia and Mazury region (voivodship). The situation of this region is special because its foreign borders were delimited in 1999 (during the Administration Division Reform) to cover the entire Polish border with the Russian Federation (Kaliningrad Oblast $<$ Region $>$ ).

The social situation has been unfavourable in the Warmia and Mazury region for many years. The basic social indexes are not only below the EU average, but also below the Polish average (see Table 1). The economic and social situation in the region is determined by:

- a high unemployment rate and low labour mobility;

- the low quality of education;

- limited accessibility to educational infrastructure;

- poor access to medical services (basic and specialist medical treatment);

- a significant shortage of palliative care services and addiction therapy;

- housing situation is below the Polish average;

- a significant share of old flats and houses built by using the obsolete technology (high-rise buildings built with large plates) ${ }^{5}$. 
A. Żukowski \& M. Chetminiak: European Union Enlargement and the New Peripheral Regions: Political, Economic and Social Aspects, and Related Issues - A Case of Warmia and Mazury Region

Table 1: Economic and social indexes of the Warmia and Mazury region in comparison with Poland and the European Union in 2005

\begin{tabular}{|l|l|l|l|l|}
\hline $\begin{array}{l}\text { No } \\
.\end{array}$ & Social indexes & Warmia and Mazury & Poland & EU-25 \\
\hline 1. & Average life expectancy & 70.0 & 70.8 & 75.8 \\
& $\begin{array}{l}\text { - male } \\
\text { - female }\end{array}$ & 79.4 & 79.4 & 81.9 \\
\hline 2. & $\begin{array}{l}\text { Number of students per } \\
\text { 10 000 inhabitants }\end{array}$ & 396.4 & 508 & 375 \\
\hline 3. & $\begin{array}{l}\text { Employment according to sectors (\%) } \\
\text { - agriculture, hunting, forestry, }\end{array}$ & 17.0 & 17.0 & 5.1 \\
& $\begin{array}{l}\text { fishing } \\
\text { - industry and construction }\end{array}$ & 28.9 & 27.9 & 25.2 \\
\hline 4. & Total employment rate (\%) & 54.1 & 55.1 & 69.7 \\
\hline 5. & Activity rate (\%) & 52.3 & 45.2 & 63.8 \\
\hline 6. & Registered unemployment rate (\%) & 27.2 & 54.9 & 69.7 \\
\hline 7. & Long-term unemployment rate (\%) & 18.3 & 17.7 & 8.8 \\
\hline 8. & GDP per capita (in euros) & 8047.9 & 10.2 & 3.8 \\
\hline 9. & $\begin{array}{l}\text { Research and development } \\
\text { expenditure in relation to GDP (\%) }\end{array}$ & 0.21 & 10215 & 21741 \\
\hline 10. & $\begin{array}{l}\text { Households with personal } \\
\text { computers and access to Internet (\%) }\end{array}$ & 17.8 & 0.60 & 1.95 \\
\hline 11. & Internet users (\%) & 14.9 & 22.5 & 49.0 \\
\hline 12. & $\begin{array}{l}\text { Development level of } \\
\text { e-public services (\%) }\end{array}$ & 23 & 22.0 & 38.0 \\
\hline
\end{tabular}

Source: Rocznik Statystyczny Województwa Warmińsko-Mazurskiego 2006, US w Olsztynie, Olsztyn 2006; Rocznik Statystyczny Województw 2006, GUS Warszawa 2006

The SWOT analysis conducted on behalf of the Regional Operational Programme for the Warmia and Mazury voivodship shows that despite disadvantages of economic and social indexes there are indicators that could be treated as assets of the region, for example,

- $\quad$ significant labour force resources,

- cultural and ethnic richness (e.g., Ukrainian and German minorities),

- the scientific and research potential of the Warmia and Mazury University in Olsztyn,

- development of other universities in the region,

- good conditions for ecological education.

It is worth mentioning that this analysis also shows a few potential opportunities (provided that the EU appropriations are appropriately utilised) that are going to slowly change the peripheral status of the Warmia and Mazury region. These 
opportunities, inter alia, are: an influx of highly qualified scientific personnel; taking advantage of the contacts between national minorities, particularly between the Germans and Ukrainians and their motherlands; developing spa and specialist healthcare; developing social services provided by non-governmental organisations; taking advantage of cultural events and initiatives to promote the region and to develop tourism; introducing law enhancing development of nongovernmental organisations ${ }^{6}$.

The Polish peripheral regions were beneficiaries of the EU appropriations already before Poland's EU accession. Since 1994, the Warmia and Mazury region has been receiving such assistance, and, inter alia, within the PHARE programme (Poland/Hungary Aid for Economic Reconstruction). The projects were primarily intended for the local infrastructure development, advanced administrator training, administrative adaptation to EU standards, and for the human resource development. It is estimated that within the first PHARE programmes, the Warmia and Mazury region received around 23 million euros. In addition, the region got:

a) 31 million euros from the Instrument for Structural Policies for PreAccession (ISPA) to fund two environmental protection projects.

b) 51 million euros from the SAPARD resources (Support for PreAccession Measures for Agriculture and Rural Development) to improve the agricultural and fish processing industry, and its marketing; to make investments in farms; to develop and improve rural areas and diversification of economic activities there.

c) c) 55.7 million euros from the Phare Economic and Social Cohesion Programme to assist the regions whose development is lagging behind; these resources were intended for narrowing the gap by creating new jobs, solving social problems, and by developing economic infrastructure.

d) 10 million euros from the Revival of Rural Areas Programme to fund the projects for developing rural infrastructure, making investments in education, and for giving micro loans and grants.

After Poland's EU accession, one of the financial instruments that would lead to the development of EU peripheral regions is the Integrated Operational Programme (IOP) of Regional Development, one of the programmes intended for the implementation of the National Development Plan 2004-2006. The programme was co-funded by the European Regional Development Fund (ERDF) and by the European Social Fund (ESF). Over the 2004-2006 period, 4.23 billion euros (out of which 2.9 billion euros from EU funds) were allocated for project implementation. The funds granted from the ERDF and ESF could not exceed 75 percent of the eligible project costs. However, due to profit generation, these funds could not exceed 50 percent of the eligible project costs if investments were made in infrastructure. No project could be simultaneously funded by both funds. At the end of 2006, the financial resources of the funds were almost entirely allocated in Poland (97.34 percent). 
The most important objectives of the Integrated Operational Programme (IOP) of Regional Development are the following:

- creating conditions for increasing regional competitiveness,

- combating marginalisation in some areas,

- being conducive to long-term economic development de market,

- being conducive to economic, social, and territorial cohesion.

Under the Integrated Operational Programme (IOP) of Regional Development, the Warmia and Mazury region received around 180 million euros during the 20042006 period. They constituted 6.59 percent of the total amount of the national financial resources. The amount of the money received per capita in the region was more than 73 percent higher than the national average. The Warmia and Mazury region occupied first place in terms of this indicator. Until March 2006, the projects that were carried out were particularly intended for modernisation and extension of the regional transport network, transport and environmental infrastructure. Considerable portions of financial resources were allocated to foster development of small enterprises (health care services, tourism, industry) and rural areas.

The Polish Ministry of Regional Development has prepared the National Cohesion Strategy for the 2007-2013 period. Thanks to the EU financial resources, the strategy is going to improve the socio-economic situation of the population in peripheral regions. The strategy is primarily intended for increasing employment through development of human and social capital, enhancing competitiveness of the Polish regions, and for counteracting their social, economic, and spatial marginalisation. Out of the 55 million euros allocated for the projects, more than 2 million euros are allocated for the development of the peripheral Polish regions, and 8 million euros for human capital.

\section{Cross-Border Cooperation between the Warmia and Mazury Region and the Kaliningrad Region}

The political consequences of EU accession are different in the new peripheral regions. They depend on the characteristics of individual countries, and on their political and socio-economic systems. It must be emphasised that the Polish peripheral regions are also border regions. This fact poses a big challenge for Poland and the European Union because both of them may take advantage of the neighbourhood of a Member State (Lithuania) and EU non-members (Russia, Belarus, and Ukraine).

It is worth mentioning that the EU introduced the European Neighbourhood Policy in 2004. Its main objective is to minimise the differences and new dividing lines between the enlarged European Union and its neighbours, and to strengthen the prosperity, stability, and security of all concerned. 
The European Neighbourhood Policy applies to the EU's immediate neighbours by land or sea from Eastern Europe, Caucasus, the Mediterranean region to the Near East. This policy also applies to the countries such as Belarus and Ukraine that have a common border with the Polish peripheral regions (Russia has concluded different agreements with the EU). The other objectives of this initiative are:

- Strengthening the political dialogue,

- Economic and social development policy,

- Trade market,

- Justice and home affairs co-operation,

- Development of neighbourhood cooperation.

The legal framework of the official relations between the EU and Russia was specified in the Partnership and Cooperation Agreement (PCA) on 24 June 1994 (it came into force on 1 December 1997). In this document, the following institutional forms of cooperation were laid down:

- as a rule, meetings will be held twice a year between the President of the European Council and the European Commission President on one side and the President of Russia on the other;

- meetings will be held at the ministerial level once a year ${ }^{8}$.

In the PCA, the necessary mutual activities are emphasised in:

- trade liberalisation;

- the political dialogue between the Parties at different levels;

- economic cooperation, particularly in the fields of technology, energy, transport, and environmental protection;

- judicial cooperation, and especially cooperation in the fields of the fight against organised crime and drug smuggling ${ }^{8}$.

However, the new stage in the relations between the EU and Russia began as late as 1999 (see: Lichacziein 2000). During this year, the next important document on cooperation was signed - the Common Strategy of the European Union on Russia (on 4 June 1999). The main objectives of this strategy are:

1. Assistance for development of a stable, open and pluralistic democracy in Russia based on the rule of law and market economy.

2. Cooperation with Russia to stabilise the situation in Europe, and to strengthen global security ${ }^{10}$

The cooperation between the EU and Russia is particularly related to the consolidation of democracy, integration of Russia into a common European economic and social space, co-operation to strengthen stability and security in Europe and beyond, co-operation with Russia on energy and nuclear safety, environment and health, the fight against organised crime, money laundering, and illicit traffic in human beings and drugs ${ }^{11}$. 
Many Russian political, economic and scientific circles have become convinced of the need for close cooperation between the EU and Russia. They point to the cooperation basics that include direct neighbourhood, political and economic transition that lead Russia to the same civilisation (Żdanow, Pustowganow, Fiodoroin 2002: 172). They require a new concept of the long-term cooperation between the EU and Russia on the development of the Kaliningrad region that will take into consideration Moscow's interests and the needs of the region (Żdanow, Pustowganow \& Fiodoroin, 2002: 172).

A New Partnership and Cooperation Agreement between the EU and Russia has not been signed until now (there are many reasons for this, e.g., Russian involvement in the war in Georgia, problems with gas delivery to the EU via Ukraine, etc.).

One of the priorities of the international and cross-border cooperation of the Warmia and Mazury region is the cooperation with the Kaliningrad region. Institutional basics of contacts are:

- intergovernmental agreements,

- agreements establishing Euroregions,

- agreements between regional and local authorities.

The cross-border cooperation has achieved a high level of institutionalisation at the national and regional levels since 1996. Such cooperation initiated by eligible entities is made possible thanks to the concluded international agreements (see Skrzydło, 1997). Therefore, the cross-border cooperation between the WarmiaMazury and Kaliningrad regions can also take place under Euroregion schemes: Euroregions „Bałtyk”, „Niemen” and also „Łyna-Ława” and „Szeszupa” (see Grzelak, 2002; Modzelewski, 2004).

The crucial matter concerning the Polish-Russian borderlands in the context of the Polish integration with the EU was the introduction of visas for the Russian citizens. Consultations to settle the problem started in March 2000. They were conducted at the Polish-Russian Foreign Ministry level. During his visit to Lithuania in April 2001, Władysław Bartoszewski, the Polish Minister of Foreign Affairs, stressed that the introduction of visas for the Russian citizens who lived in the Kaliningrad region was necessary. However, he stressed that the Polish side would not hurry to introduce the visas ${ }^{12}$. In February 2002, the Polish authorities announced that visa duty was expected to be introduced in July 2003. The Russian side was critical about such announcements. Dimitry Rogozin, Chairman of the International Affairs Committee in the lower house of the Russian State Duma, even stated that Warsaw and Vilnius' intention to introduce a visa regime for all the Russian citizens “(...) would threaten the Russian Federation citizens' right to free movement all over the country" " Another representative of the Russian side, Alexander Yakovenko, Deputy Minister of Foreign Affairs, claimed that the 
introduction of visa was not expected to deteriorate relations between the two countries $^{14}$. Both sides agreed that there should be inexpensive multiple-entry visas for the Russian citizens (unfortunately, a one-year multiple-entry visa was expensive). The visa introduction deadline was rescheduled until 1 January 2003. On that date, Poland denounced the Polish-Russian agreement on non-visa movement.

The introduction of a visa regime affected cooperation on the Polish eastern border and in the Polish-Russian borderlands. Firstly, when crossing the EU external border there might be some cumbersome border formalities however, they are not obstacles to the development of cross-border cooperation. Secondly, during the first 20 months of the visa regime being in force, a major reduction of arrivals to Poland on its eastern border was recorded (Sidorowicz 2005: 244).

After Poland's accession to the European Union, it was important to avoid the situation in which the Polish-Russian border would constitute a hindrance to cooperation (see Żukowski 2004). By counteracting against that, the EU supported the Lithuania, Poland and Kaliningrad Region of Russian Federation Neighbourhood Programme (INTERREG III A / TACIS) that was carried out in years 2004-2006. The funds that the Warmia and Mazury region received from the European Regional Development Fund under the INTERREG III A / TACIS programme amounted to 4.8 million euros, which constitute 14 percent of the state funds. Out of this amount, nearly 1.6 million euros were allocated for the projects concerning development of tourism and its infrastructure, as well as restoration of cultural heritage objects of cross-border significance. More than 1 million euros were allocated for the activities on the Polish-Russian state border, including the Elbląg seaport development. The rest of the funds were allocated for the environmental protection projects.

After 1 May 2004 (despite the growth of the New Euroregions „Szeszupa” and „Łyna - Ława”), the Bałtyk Euroregion still plays the most important role in the cross-border cooperation between the Warmia-Mazury and Kaliningrad regions. It was primarily established to turn bilateral cooperation into a multilateral one. The next reason for its establishment was a strong possibility of getting EU funding. The Battyk Euroregion has no legal person status, but the Association of Municipalities of the Republic of Poland has (Stowarzyszenie Gmin RP Euroregionu „Bałtyk”). During works connected with establishing Euroregion "Bałtyk," Bronisław Geremek, the Polish Minister of Foreign Affairs, pressed to include the Kaliningrad region as a participant in cooperation. It would be the first participation of a Russian region in the Euroregion structure of cooperation. The most inactive member of the Battyk Euroregion has been Latvia since the beginning of the Euroregion. Latvia has been more engaged in bilateral projects with Sweden. 
Poland held Chairmanship of the Bałtyk Euroregion in 2004 (the Chairman was Jan Kozłowski, Pomeranian Voivodship Marshal). The Euroregion secretariat is situated in Elbląg in the Warmia and Mazury region. All members cover the Euroregion activity costs. The Danish and Swedish regions pay the highest fees, i.e., 6,000 euros a year. The Polish regions pay 3,000 euros. The lowest fees are paid by the Latvian, Lithuanian, and Kaliningrad regions. Since the end of March 2006, the Kalinigrad region held chairmanship of the Bałtyk Euroregion for oneyear term.

The funds, which the Euroregion could obtain prior to the EU enlargement in 2004, were divided into three groups:

1. Interreg (Sweden, Denmark),

2. Phare (Poland, Lithuania, Latvia),

3. Tacis (Russia).

Under the Bałtyk Euroregion programmes, Poland received 9 million euros. The rate of utilisation of appropriations reached more than 90 percent, and in comparison with other Euroregions in which Poland participated, it was the highest. Most funds were allocated for the projects concerning the youth and children exchange, cooperation of universities, and assistance for the handicapped. The last implemented project Seagull 2 concerned four areas of cooperation:

1. Competitive business environment (innovations, support for small and medium-sized enterprises (SME), agriculture, tourism).

2. Transport infrastructure (lobbying for the trans-European transport infrastructure network in the Baltic Sea region).

3. Social dimension (a common labour market).

4. Environmental protection and renewable energy sources.

During working out the project, it was said to add a fifth area of cooperation, i.e., the cooperation with the Kaliningrad region. Finally, it was decided that the Kaliningrad region problems would be included in four areas of cooperation.

The support processes of the Kaliningrad region development could also be a great opportunity for the Warmia and Mazury region. High economic and social growth of the regions and state borders in Poland is one of the conditions to minimise the disadvantages of the EU external border along the Polish eastern border. The socalled "peripherisation" of the Warmia-Mazury and other Polish peripheral regions in the European space could be avoided if those regions became fully integrated with the EU as emerging markets and space of massive capital investment.

The Polish Parliament, Government, President, and local self-government should be responsible for implementation of new directions of the Polish regional policy. 
It is stated that Poland should get permission of the Commission of the European Communities for a new approach to regional policy ${ }^{15}$.

\section{Conclusion}

Regional lobbying plays an important role in the European Union. Therefore, the Polish peripheral regions, including the Warmia and Mazury region, have their own representatives in Brussels. Their lobbying should focus on the following actions:

- lobbying for the EU projects submitted by regional institutions;

- representation of interests, problems and public opinion towards the Commission of the European Communities and the European Parliament;

- maintaining contacts with the EU politicians, clerks, and experts;

- regional interest representation in associations and interests groups functioning in Brussels;

- maintaining working contacts with the representatives of partnership regions;

- gaining information on the EU resources for funding regional projects;

- preparing the visits of politicians and administration staff from the region $^{16}$.

In 2004, the Warmia and Mazury region faced some new challenges associated with the Polish accession to the EU. The years of Poland's membership in the European Union have been a period of gaining experience in submitting the EU projects for the region, and in allocating financial resources properly. The total effect of this period is rather positive. However, we must not forget that many negative economic and social phenomena still occur (e.g., a high unemployment rate, emigration of young educated people, etc.). Politically, a new challenge for the Warmia and Mazury region is going to be a continuation and development of the cross-border cooperation with the Kaliningrad region. Poland's accession to the EU has had no positive impact on improving the Polish-Russian relations at the central decision-making level. The cooperation at the regional and local levels is conducted in a much better atmosphere, although there has been no increase in the anticipated cooperation. 
A. Żukowski \& M. Chetminiak: European Union Enlargement and the New Peripheral Regions: Political, Economic and Social Aspects, and Related Issues - A Case of Warmia and Mazury Region

\section{Notes}

1 According to the official Polish administrative division terminology, region means voivodship.

2 There are seven "outermost regions" in the EU (according to Article 299): Guadeloupe, French Guiana, Martinique, and Réunion (the four French overseas departments), the Canaries (Spain), and the Azores and Madeira (Portugal). Those regions are distinguished by their low population density and considerable distance from mainland Europe.

${ }^{3}$ Such comparison was surely exaggerated, but it showed more an atmosphere (which dominated among the Polish politicians, scholars, and experts before joining the EU) than the real results of Poland's EU accession. The results could be judged only after several years.

${ }^{4}$ Bański, J., Suburban and peripheral rural areas in Poland - the balance of development in the transformation period, http://www.igipz.pan.pl/zpz/banski/PDF/9_Suburban_and.pdf.

${ }^{5}$ Regionalny Program Operacyjny Województwa Warmińsko-Mazurskiego na lata 20072013, http://www.mrr.gov.pl/Regiony/warminsko-mazurskie/Regionalny+Program+Opera cyjny $+2007+2013 /$.

${ }^{6}$ Ibidem.

${ }^{7}$ Communication from the Commission. European Neighbourhood Policy Strategy Paper, Brussels, 12.05.2004, p. 13-18.

${ }^{8}$ Agreement on Partnership and Cooperation. 24.06.1994, http://www.europa.eu.int.

${ }^{9}$ Ibidem.

${ }^{10}$ Common Strategy of the European Union of 4 June 1999 on Russia. „Official Journal of the European Communities" 24.06.1999, http://www.europa.eu.int.

${ }^{11}$ Ibidem.

${ }^{12}$ Nowy Beneluks na wschodzie Europy. PAP, 20.04.2001, http://www.euro.pap.net.pl.

${ }^{13}$ Problem Kaliningradu można rozwiązać w kilku etapach. PAP, 19.06.2002, http://www.euro.pap.net.pl.

${ }^{14}$ Wizy nie pogorszą relacji obu państw. PAP, 21.02.2002, http://www.euro.pap.net.pl.

${ }^{15}$ G. Gorzelak, op. cit., p. 71-72.

${ }^{16}$ P. Mrozowska, Polski lobbing regionalny w Unii Europejskiej, in: Polska w Unii Europejskiej. Bilans otwarcia, ed. J. Marszałek-Kawa, Toruń 2005, p. 117.

\section{References}

Buelens, J., Rihoux, B. \& Deschouwer, K. (eds.) (2008) Tussen kiezer en hoofdkwartier. De lokale partijafdelingen en de gemeenteraadsverkiezingen van 2006 (Brussel: VUBPRESS).

Gorzelak G. (2002) Polskie regiony w procesie integracji europejskiej, Studia Regionalne $i$ Lokalne, (9)2-3, pp. 55-74.

Grzelak G. (2002) Pomorze i Obwód Kaliningradzki - współpraca międzynarodowa 1992 2002, Gdańskie Studia Międzynarodowe, 1(2), pp. 35-46.

Kawałko B. (2006) Granica wschodnia jako czynnik ożywienia $i$ rozwoju społecznoekonomicznego regionów przygranicznych (Warsaw: Ministerstwo Rozwoju Regionalnego), pp. 35.

Kruszewska-Gagoś M. (2006) Promowanie rozwoju i dostosowań strukturalnych w regionach słabiej rozwiniętych jako jeden $\mathrm{z}$ celów polityki regionalnej Unii 
Europejskiej, In: Plawgo B. (ed.) Polska Wschodnia - determinanty rozwoju (Białystok: WSAP), pp. 31-46.

Kukliński A. (1999) Unia Europejska jako przełomowe wyzwanie dla Polski XXI wieku (artykuł dyskusyjny), Studia Europejskie, 1(3), pp. 11-24.

Lichacziein W. (2000) Rossija i Jewropejskij Sojuz w stratiegiczieskoj pierspiektiwie, Mieżdunarodnaja Żizń, 34(1), p. 40-49.

Modzelewski W. T. (2004) Współpraca na pograniczu polsko-rosyjskim. Wymiar regionalny i lokalny, in: Żukowski A. (ed.) Polska wobec Obwodu Kaliningradzkiego Federacji Rosyjskiej (Olsztyn: INP UWM), pp. 77-78.

Mrozowska P. (2005) Polski lobbing regionalny w Unii Europejskiej, In: Marszałek-Kawa J. (ed.) Polska w Unii Europejskiej. Bilans otwarcia (Toruń: Adam Marszałek), pp. 150-165.

Sidorowicz L. \& Bociania K. (2005) Próba weryfikacji nowego wymiaru polskiej granicy państwowej w zakresie przepływu osób po akcesji do Unii Europejskiej, In: Sikorski, J. (ed.) Regiony przygraniczne $w$ warunkach zewnętrznych granic Unii Europejskiej, (Białystok: Wydawnictwo Uniwersytetu w Białymstoku), p. 305.

Skrzydło A. (1997) Rozwój współpracy transgranicznej i międzyregionalnej, In: Wizimirska, B. (ed.) Rocznik Polskiej Polityki Zagranicznej 1997 (Warsaw: PISM), pp. 86-88.

Żdanow W. P., Pustowganow W. I. \& Fiodoroin G. M. (2002) Prostranstwiennoje razwitie ekonomiki i rassielienia riegiona (Kaliningrad: BIEF), pp. 232.

Zięba R. (2000) Polityka zagraniczna Unii Europejskiej wobec Europy Środkowej i Wschodniej, Stosunki Międzynarodowe, 22(3-4), pp. 9-24.

Żukowski A. (2004) New border of the European Union with the Kaliningrad District from the perspective of the Polish foreign policy, In: Wendt J., Bente F. \& Bodocan V. (eds.) Poland and Romania before Enlargement of European Union and NATO, (Warsaw: Carta Blanca), pp. 143-156. 